\title{
Spleen and gone? An interesting case of fever in a young man
}

\author{
Christopher Myles Rowe, ${ }^{1}$ Caroline Spillane, ${ }^{2}$ Dario Winterton, ${ }^{3}$ \\ Laura-Beth Pilkington ${ }^{3}$
}

${ }^{1}$ Whittington Health NHS Trust, London, UK

${ }^{2}$ University of Warwick, Warwick Medical School, Coventry, UK

${ }^{3}$ Queen's Hospital, Burton upon Trent, Staffordshire, UK

\section{Correspondence to} Dr Christopher Myles Rowe, christopher.m.rowe@doctors. net.uk

Accepted 16 May 2016
CrossMark

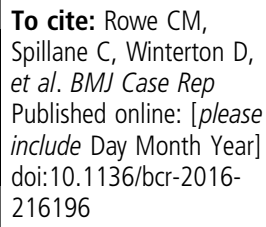

\section{DESCRIPTION}

A 38-year-old man attended accident and emergency department (A and $\mathrm{E}$ ) reporting of a 2-week history of fever and rigors, vomiting and left flank pain.

The patient had a medical history of hypertension and obesity, but denied being diabetic and had not recently travelled. Later history taking did not reveal any abdominal trauma.

Abdominal examination elicited pain in the left upper quadrant, but no palpable mass. Cardiovascular examination revealed the patient to be peripherally warm and tachycardic, with a flash capillary refill, but normotensive. The patient was febrile at $39.0^{\circ} \mathrm{C}$. All other examinations were normal.

Admission blood tests demonstrated a white cell count of $40.0 \times 10^{9} / \mathrm{L}$, and C reactive protein of $155 \mathrm{mg} / \mathrm{L}$. Liver function tests, and urea and electrolytes were normal. Urine dip was negative and admission chest $\mathrm{X}$-ray was normal.

An ultrasound of the abdomen was undertaken, which revealed a heterogenic encapsulated mass in the superior aspect of the spleen, containing echogenic clumps, with the appearance of an organising abscess. A subsequent abdominal CT showed a welldefined large splenic abscess (figure $1 \mathrm{~A}-\mathrm{C}$ ) with mildly thick fluid content, tiny calcifications along the upper medial contour and loculated gas.

A percutaneous drain was placed, from which puss drained; culture and sensitivities grew Escherichia coli.

The patient was discharged with antibiotics and the drain in situ; however, 3 days later, he re-presented to $\mathrm{A}$ and $\mathrm{E}$ describing the recurrence of fever and rigors. Clinical examination revealed diffuse upper abdominal pain, a heart rate of $130 \mathrm{bpm}$, blood pressure of $85 / 40 \mathrm{~mm} \mathrm{Hg}$, and an arterial blood gas revealing metabolic acidosis and lactic acidaemia-all indicative of sepsis.

A repeat abdominal CT revealed recurrence of the splenic abscess. After fluid resuscitation, the patient attended surgery for a splenectomy and, postoperatively, the intensive care unit (ICU) for vasopressor support and escalated antibiotic therapy. A transthoracic echocardiogram undertaken on the ICU was normal.

During both attendances, clinical and radiological investigations did not reveal an obvious source for the splenic abscess. The most common causes of splenic abscesses are haematogenous spread from distant infections, including endocarditis, ${ }^{1}$ or contiguous spread from infections of the adjacent/local anatomy. ${ }^{1}$ Trauma is a predisposing factor. The most common causative pathogens are aerobes, including the Gram-positive organisms Streptococcus viridans, Enterococcus sp. and
Staphylococcus aureus, ${ }^{1}$ and the Gram-negative pathogens E. coli and Klebsiella pneumonia. ${ }^{1}$ Up to half of the cases are polymicrobial. ${ }^{1}$ Less common causative pathogens can include anaerobes, Mycobacterium tuberculosis and fungal infections. ${ }^{1}$
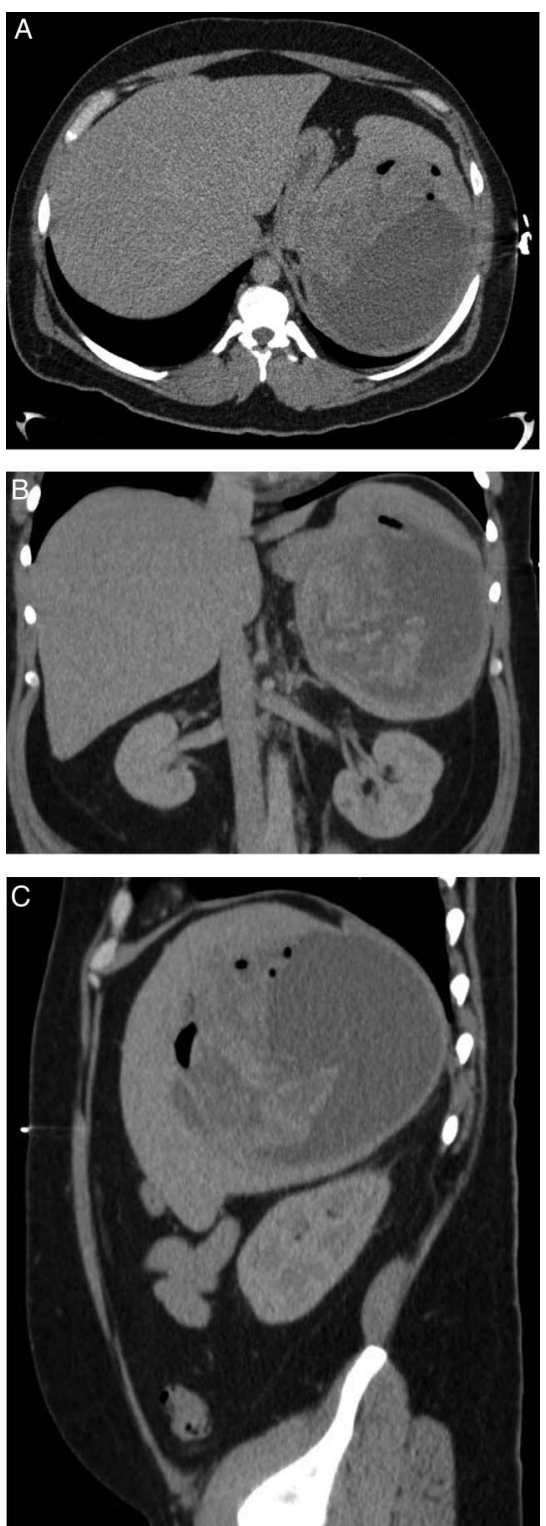

Figure 1 (A-C) CT of the abdomen-axial, coronal and sagittal views (respectively), demonstrating an enlarged spleen and abscess, revealing liquefaction of the posterior and inferior aspect of the spleen and gas collections, with relative preservation of the superior and anterior spleen parenchyma. Note the compression of the stomach (axial view). 


\section{Learning points}

- Splenic abscesses are rare. ${ }^{12}$ A classic triad of fever $(92 \%$ of cases) ${ }_{1}{ }^{2}$ left upper quadrant pain $(77 \% \text { of cases })^{2}$ and leucocytosis $(66 \% \text { of cases) })^{2}$ has been described, but symptoms are often non-specific. Potential signs may be local, namely splenomegaly or distant, from other organ system examinations, including heart murmurs from infective endocarditis. $^{1}$

- Splenic abscesses can potentially present as solitary or multiple abscesses, with extrasplenic abscesses. ${ }^{1}$ Major risk factors for splenic abscesses are concomitant underlying disease $^{1}$ and immunosuppression; with diabetes mellitus being the most common predisposing factor. ${ }^{1}$
The patient made a full recovery and was discharged home with prophylactic penicillin $\mathrm{V}$ (against capsulated bacteria postsplenectomy), to be taken for life.

Acknowledgements The authors would like to thank Dr El-Badawy (consultant radiologist) for his advice and teaching regarding the images.

Competing interests None declared.

Patient consent Obtained.

Provenance and peer review Not commissioned; externally peer reviewed.

\section{REFERENCES}

1 Chang KC, Chuah SK, Changchien CS, et al. Clinical characteristics and prognostic factors of splenic abscess: a review of 67 cases in a single medical center of Taiwan. World J Gastroenterol 2006;12:460-4.

$2 \mathrm{Ng} \mathrm{KK}$, Lee TY, Wan YL, et al. Splenic abscess: diagnosis and management. Hepatogastroenterology 2002;49:567-71.

Copyright 2016 BMJ Publishing Group. All rights reserved. For permission to reuse any of this content visit http://group.bmj.com/group/rights-licensing/permissions.

BMJ Case Report Fellows may re-use this article for personal use and teaching without any further permission.

Become a Fellow of BMJ Case Reports today and you can:

- Submit as many cases as you like

- Enjoy fast sympathetic peer review and rapid publication of accepted articles

- Access all the published articles

- Re-use any of the published material for personal use and teaching without further permission

For information on Institutional Fellowships contact consortiasales@bmjgroup.com

Visit casereports.bmj.com for more articles like this and to become a Fellow 